\title{
OVERRIDING MANDATORY PROVISIONS IN CROATIAN PRIVATE INTERNATIONAL LAW**
}

Summary: $\quad$ Overriding mandatory provisions are mandatory provisions that are applicable in situations with an international element. The author analyses overriding mandatory norms in the European private international law and in the Croatian national private international law. The definition of such norms provided in the 2017 Croatian Private International Law Act is almost a verbatim copy of the definition provided in the Rome I Regulation on the law applicable to contractual obligations. The 1982 Croatian Private International Law Act did not provide for a definition of overriding mandatory norms but it was uniformly accepted in the scholarly interpretations that those types of mandatory norms were accepted by the Croatian private international law system. Moreover, the 1982 PIL Act included a substantive family law provision, which was, in essence, an overriding mandatory provision. However, Croatian courts and practitioners have been reluctant to refer explicitly to an applied norm as an overriding mandatory one. The reasons behind that might be that that the courts were better acquainted with the public policy exception, since public policy was explicitly mentioned in the 1982 PIL Act, as well as in some other legal acts. In addition, the legislator does not explicitly note that a provision is an overriding mandatory one in the provision itself, which leads to the outcome that the courts and other practitioners are burdened with a complex task of interpretation of a provision they think might be an overriding mandatory one. The author aims at providing guidelines to facilitate that task.

Keywords: $\quad$ overriding mandatory provisions, Rome I Regulation, 2017 Croatian Private International Law Act, regulatory norms

Dora Zgrabljić Rotar, PhD, Assistant Professor, Faculty of Law, University of Zagreb, Trg Republike Hrvatske 14, 10000 Zagreb, Republic of Croatia. E-mail address: dora.zgrabljic.rotar@pravo.hr. ORCID: https://orcid.org/0000-0002-6558-4532.

** The paper is a result of the research conducted for the EAPIL Young EU Private International Law Research Network conference on Overriding Mandatory Rules in the Law of the EU Member States. 


\section{INTRODUCTION}

In cross-border relationships, the law applicable to the merits of the case is determined in accordance with the conflict-of-laws rules of the forum. Notwithstanding whether the applicable law was chosen by the parties or determined in accordance with the appropriate conflicts rule, the law applies in full, i.e. including its dispositive as well as its mandatory norms. In essence, mandatory norms of all other legal systems are excluded, even if the legal system is closely connected to the dispute. However, most legal systems (both civil and common law) acknowledge the idea that certain mandatory rules are applicable even if a situation includes an international element. ${ }^{1}$ Those types of mandatory norms are called overriding mandatory norms and are known by various names in different jurisdictions: lois de police or lois d'application immédiate, Eingriffsnormen, norme di applicazione necessaria, pravila neposredne primjene.

It has been well established that the overriding mandatory norms of the forum apply in a situation with an international element. The newest developments in the EU private international law also establish that the application of overriding mandatory norms of a third country is appropriate in certain cases. Croatian legal system also acknowledges both possibilities in theory, however they seem to have been rarely used in practice.

Overriding mandatory norms are sometimes described as a private international law method $^{2}$ by which the state protects its own public policy. Overriding mandatory norms are mandatory norms which should be applied in all cases, notwithstanding whether or not a case involves an international element. All overriding mandatory norms are mandatory norms, but not all mandatory norms are overriding mandatory norms. The aim of overriding mandatory norms is to protect the international public policy in the same manner as mandatory norms protect the domestic public policy. ${ }^{3}$

Phocion Francescakis was the first to describe the overriding mandatory provisions as the norms necessary to protect the political, social and economic order of a country. ${ }^{4}$ Since then those provisions have been described and acknowledged in almost all legal systems and have been introduced into the European private international law through regulations and case law of the CJEU. Scholars and practitioners do not question the fact that the parties cannot avoid the application of the overriding mandatory provisions. ${ }^{5}$ Nevertheless, understanding and applying overriding mandatory norms to this day presents a serious challenge to practitioners.

Namely, even though it is the will of the legislator that determines whether a substantive law provision should be applied as an overriding mandatory norm, it is almost never or very rarely clearly determined in the rule itself, making it susceptible to interpretation. Some gui-

1 Gralf-Peter Calliess, Rome Regulations - Commentary (2nd edn, Wolters Kluwer 2015) 242.

2 Krešimir Sajko, Međunarodno privatno pravo (Narodne novine 2009) 279; Ivana Kunda, 'Defining Intenationally Mandatory Rules in European Private International Law of Contracts' (2007) 4(5) Zeitschrift für Gemeinschaftsprivatrecht 210.

3 Hrvoje Sikirić, 'Prisilna pravila, pravila neposredne primjene i mjerodavno materijalno pravo u međunarodnoj arbitraži' (1999) 38(1) Pravo u gospodarstvu 83-85

4 Phocion Francescakis, 'Quelques précisions sur les «lois d'application immediate» et leurs rapports avec les règles sur les conflits de lois' [1966] 55 RCDIP 11-18. 
delines on the valorisation of certain legal provision as internationally mandatory provisions are, nevertheless, described and accepted by scholars and in case law.

The importance of overriding mandatory norms in cross border transactions is increasing as a consequence of the increase of regulatory rules. ${ }^{6}$ Regulatory norms are influencing all areas of private rights and obligations with the aim to protect national public policy aims but also global public goods, such as the environment, or fight against a pandemic. ${ }^{7}$ The focus of private international law is, thus, not limited to the most closely connected law any more - it is now broadened to include overriding mandatory norms that regulate national and supranational global interests. ${ }^{8}$ In this paper, the author will explore the reasons why the courts seem to be reluctant to give an overriding mandatory effect to a legal provision and give some guidelines on how to determine whether a provision found in the Croatian legal system can be regarded as an overriding mandatory norm. The aim is to reassure the courts and practitioners that the application of overriding mandatory provisions is well established in the system of private international law. In the first part of the paper overriding mandatory norms will be described in general (2.). In the second part of the paper the author focuses on the overriding mandatory norms in the European private international law system (3.) with special attention devoted to the overriding mandatory norms of third countries (3.2.). In the third part the author analyses overriding mandatory norms in the Croatian private international law system. Firstly, the overriding mandatory norms in Croatian law and practice before the 2017 Croatian PIL Act (4.1.). Secondly, the overriding mandatory provisions after the 2017 Croatian PIL Act (4.2.). Author's concluding remarks provide a guideline to the application of overriding mandatory provisions in Croatia (5).

\section{WHICH NORM IS AN OVERRIDING MANDATORY NORM?}

In order to recognize a legal provision as an overriding mandatory norm, a judge or a practitioner has to conduct a thorough and layered analysis. It is a difficult task in case when one is within the boundaries of the domestic legal system and it can become an insurmountable one in case of the application of a third countries' overriding mandatory norm.

It is certain that the norm has to be a mandatory provision. So, the first question one asks himself is: is the applicable provision a mandatory one? However, even this, at first sight, easy question is often difficult to answer. Namely, in some legal systems the distinction between mandatory provisions and the provisions that are not mandatory is blurred. ${ }^{9}$ Some authors even claim that a categorical difference between mandatory and non-mandatory rules does not exist. ${ }^{10}$ It is, however, a fact that all national legal systems within the EU acknowledge

\footnotetext{
$6 \quad$ Calliess (n 1) 243.

7 Matthias Lehmann, 'Regulation, global governance and private international law: squaring the triangle' (2020) 16(1) Journal of Private International Law 1.

8 Ibid 30

$9 \quad$ Calliess (n 1) 246. 
the difference between mandatory and non-mandatory rules. ${ }^{11}$ Albeit, mandatory rules are not the same rules in every Member State, ${ }^{12}$ i.e. a rule that is mandatory in France might not be mandatory in Germany. Even though in some European legal systems, such as French or German, it is sometimes explicitly pointed out in the rule itself that the rule should be applied as a mandatory one, it is mostly up to the courts to determine, based on the intention of the legislator, that the rule is indeed mandatory.

To determine that a provision is mandatory is also a complex task in the Croatian legal system. The evidence to the complexity of this task are decisions of the courts of appeal in which they quash the lower courts' decisions based on the misinterpretation of whether a certain provision is mandatory or not. ${ }^{13}$

Albeit not all mandatory provisions are internationally mandatory. It is, thus, important to determine that the norm aims to protect the highest public interests of a certain state. ${ }^{14}$ What exactly constitutes a public interest is difficult to define, especially because public interest, which is an abstract term, is mostly defined by using other abstract notions such as the protection of 'political, social and economic organisation'. ${ }^{15}$ In the European Union, both national courts and the CJEU have taken the stand that the regulatory norms in essence protect such interests and are thus considered as overriding mandatory norms. ${ }^{16}$

Overriding mandatory norms are found in the sphere of both public, as well as private law. ${ }^{17}$ Their common feature is that they aim at the protection of a public interest. ${ }^{18}$

However, even if one can decide that a norm protects the highest public interests of its own domestic legal system, it will be extremely difficult to know whether a norm protects the highest public interests in a foreign legal system. To know that, one has to acquaint himself with the constitutional framework and the legal order of the foreign country in question. ${ }^{19}$ In most cases, it will be easier if a norm belongs to the sphere of regulatory rules, since in that case it will presumably be acceptable to apply it as an overriding mandatory norm regardless of the national origin of the norm.

The problem of the regulatory rules as internationally mandatory ones, on the other hand, lies in the fact that, in the vast majority of cases, they belong to the sphere of public law. Since the courts regularly refuse to apply public law rules of other states, the courts would, presuma-

\footnotetext{
11 Ibid 56-62.

12 Ibid.

13 E.g. Court ruling Rev-x 876/13-3, Supreme Court of the Republic of Croatia (30 September 2014) (HR).

14 Kunda (n 2) 213; Calliess (n 1) 247.

15 Calliess (n 1) 247; Michael Hellner, 'Third Country Overriding Mandatory Rules in the Rome I Regulation: Old Wine Bottles?' (2009) 5(3) Journal of Private International Law 449.

16 Calliess (n 1) 248

17 Sikirić (n 3) 86; Callies (n 1) 247; Dieter Martiny, 'Rom I-VO Art. 14 Rom I-VO Übertragung der Forderung' in Franz Jürgen Säcker and others (eds), Münchener Kommentar zum Bürgerlichen Gesetzbuch: BGB (CH Beck 2018) rn 12; Giuditta Cordero-Moss, 'EU Overriding Mandatory Provisions and the Law Applicable to the Merits' in F Ferrari (ed), The Impact of EU Law on Commercial Arbitration (Juris 2017) 318.

18 Calliess (n 1) 247.

19 Andrew Dickinson, 'Third-Country Mandatory Rules in the Law Applicable to Contractual Obligations: So Long, Farewell, Auf Wiedersehen, Adieu?' (2007) 3(1) Journal of Private International Law 68.
} 
bly, be reluctant to apply regulatory norms as overriding mandatory rules of any other state but the state of the forum. ${ }^{20}$ There is however an opinion that the old strict division between the willingness to apply foreign private law and the refusal to apply foreign public law should be abolished because public law, especially in its regulatory role, is increasingly becoming a result of global and international cooperation with the aim to protect and serve, not only individual national legal systems, countries and its citizens but to protect the global order. ${ }^{21}$

Problems with declaring all regulator norms as overriding mandatory norms can occur in the country of the forum as well. Namely, if we find that most or all regulatory norms have to be applied as overriding mandatory rules, that could lead towards a unilateral application of those types of rules in every situation with a consequence of the application of domestic law over the law determined by the domestic conflict-of-laws rules. ${ }^{22}$

Should we then concede that all regulatory norms are overriding mandatory norms and apply them in all situations, even the ones with an international element? Or should we undertake another layer of analyses and distinguish the regulatory norms which are overriding mandatory rules from the ones that are not?

The answer to that question is provided in the definition of the overriding mandatory rules which in the EU puts the greatest emphasis on the preservation of the highest, crucial public interests of a country. Namely, although the purpose of mandatory rules is to protect the interests of the State itself and to protect private interests that the State wishes to protect, ${ }^{23}$ not all state interests are crucial for safeguarding its public interests. It would, thus, be advisable to scrutinize each regulatory provision before we apply it as an overriding mandatory norm since not all regulatory norms protect the crucial state interests.

\section{OVERRIDING MANDATORY NORMS IN THE EU PRIVATE INTERNATIONAL LAW SYSTEM}

\subsection{REGULATION OF THE OVERRIDING MANDATORY NORMS IN THE EU PIL}

The Rome Convention on the law applicable to contractual obligations, which represents the first step towards the unification of conflict-of-laws in the European Union, had a provision that lead to the application of mandatory norms that we now define as the overriding mandatory norms. ${ }^{24}$ It has been explained that the provision 'merely embodies principles which already exist in the laws of the Member States of the Community' ${ }^{25}$ thereby acknowl-

\footnotetext{
20 Lehmann (n 7) 6.

21 Ibid 7-10.

22 Ibid.

23 Peter Nygh, Autonomy in International Contracts (Clarendon Press 1999) 203.

24 Convention on the law applicable to contractual obligations opened for signature in Rome on 19 June 1980 [1980] OJ L 266/1, art 7.

25 Report on the Convention on the law applicable to contractual obligations by Mario Giuliano, Professor, University of Milan, and Paul Lagarde, Professor, University of Paris I [1980] OJ C282/1, art 7.
} 
edging the fact that the concept of overriding mandatory norms is well established in all legal systems of the EU Member States. Apart from giving the national MS courts the green light to apply the overriding mandatory norms of the lex fori, the Rome Convention paved the way for the application of the overriding norms of a third country if the situation has a close connection to that country and with attention to the nature and purpose of those norms, as well as the consequences of their application or non-application.

The definition of the overriding mandatory norms similar to the one provided by Francescakis was given by the Court of Justice of the European Union (CJEU) in its Arblade judgment. ${ }^{26}$ Namely, the Court described the norms as 'national provisions compliance with which has been deemed to be so crucial for the protection of the political, social or economic order in the Member State concerned as to require compliance therewith by all persons present on the national territory of that Member State and all legal relationships within that State'. ${ }^{27}$

The first legislative definition of the overriding mandatory provisions provided in the Rome I Regulation, followed the lead of the CJEU given in the Arblade decision. ${ }^{28}$ According to Article 9 (1) of the Rome I Regulation, overriding mandatory provisions are provisions the respect for which is regarded as crucial by a country for safeguarding its public interests, such as its political, social or economic organisation, to such an extent that they are applicable to any situation falling within their scope, irrespective of the law otherwise applicable to the contract under the Rome I Regulation. The Rome I Regulation authorises courts to apply the overriding mandatory provisions of the lex fori. In addition, effect may be given to the overriding mandatory provisions of the law of the country where the obligations arising out of the contract have to be or have been performed, in so far as those overriding mandatory provisions render the performance of the contract unlawful.

Thus, there are two important novelties introduced by the Rome I Regulation - it has provided for the first legislative definition of the overriding mandatory norms and it has significantly restricted the application of the third countries' overriding mandatory norms. The function of this provision remained the same - to ensure a balance between the interests of the parties that are protected throughout the Regulation and the fundamental interests of the connected state. ${ }^{29}$

The Court of Justice of the European Union addressed the issue of overriding mandatory provisions in the seminal Ingmar decision. ${ }^{30}$ The case involved a company seated in the UK and a company seated in California, USA. The Court held that Articles 17 and 18 of the Commercial Agency Directive were overriding mandatory provisions pursuant to Article 7 of the Rome Convention and that those provisions had to be applied notwithstanding the fact that the parties agreed on the application of the law of California. Namely, the Court argues that the rules of the Directive that aim at the protection of the commercial agents after the terminati-

26 Joined Cases C-369/96 and C-376/96 Criminal proceedings against Jean-Claude Arblade and Arblade \& Fils SARL and Bernard Leloup, Serge Leloup and Sofrage SARL [1999] ECR I-8453, para 30.

27 Ibid.

28 Regulation (EC) No 593/2008 of the European Parliament and of the Council of 17 June 2008 on the law applicable to contractual obligations (Rome I) [2008] OJ L177/6.

29 Ulrich Magnus and Peter Mankowski, European Commentaries on Private International Law: Rome I Regulation (Sellier 2017 ) 604. 
on of the contract are mandatory in nature ${ }^{31}$ and that, although they aim at the protection of private interests, in a broader sense, they serve a public purpose, i.e. the rules 'protect, for all commercial agents, freedom of establishment and the operation of undistorted competition in the internal market'. ${ }^{32}$

At the time when the decision was rendered understandable critics were pointed out in relation to the Ingmar decision. There was a legitimate fear that this type of interpretation might lead to declaring all European mandatory norms internationally mandatory. ${ }^{33}$ This would be especially harmful to the parties' freedom to choose the applicable law which is guaranteed by the Regulation and is considered to be the cornerstone of the European private international law. This aim has, however, been achieved through the text of the Rome I Regulation in its article 3 paragraph 4 which leads, basically, to exactly that result. ${ }^{34}$

In the Unamar decision ${ }^{35}$ of the CJEU on the interpretation of the application of overriding mandatory provisions according to article 7 of the Rome Convention and article 9 of the Rome I Regulation ${ }^{36}$ the Court confirmed the freedom of the national courts to decide whether a norm, even in a case when it stems from a secondary European law, should be applied as an overriding mandatory one. The dispute arose from a commercial agency contract concluded between United Antwerp Maritime Agencies (Unamar) NV (Unamar), a company incorporated in Belgium, and Navigation Maritime Bulgare (NMB), a company incorporated in Bulgaria. The contract provided for application of Bulgarian law and for dispute resolution by the arbitration chamber of the Chamber of Commerce and Industry in Sofia (Bulgaria). However, CJEU decided that the provision of the law of the forum that implement the Commercial Agency Directive can be applied as overriding mandatory norm of the forum instead of the law of a Member State chosen by the parties even if that Member State had correctly implemented the minimum protection standard of the Commercial Agency Directive.

The Court confirmed that provisions of national law designed to protect commercial agents, i.e. private interests, may have overriding mandatory status if the forum State holds 'it to be crucial, in the legal order concerned, to grant the commercial agent protection going beyond that provided for by the directive. ${ }^{37}$ Although in the Unamar decision the Court does instruct the national court to interpret the provisions of article 7 of the Rome Convention and article 9 of the Rome I Regulation restrictively, the Court fails in providing guidelines as to

31 Ibid para 20-22.

32 Ibid para 24.

33 Ivana Kunda, 'Međunarodno prisilni propisi prema Europskom sudu pravde: C-381/98 Ingmar GB Ltd protiv Eaton Leonard Technologies Inc.' (2004) 6(1-2) Revija za evropsko pravo 65.

34 According to article 3(4) of the Rome I Regulation where all other elements relevant to the situation at the time of the choice are located in one or more Member States, the parties' choice of applicable law other than that of a Member State shall not prejudice the application of provisions of Community law, where appropriate as implemented in the Member State of the forum, which cannot be derogated from by agreement.

35 Case C-184/12 United Antwerp Maritime Agencies (Unamar) NV v Navigation Maritime Bulgare [17 October 2013] ECLI:EU:C:2013:663.

36 The court clearly states that the interpretation of the Court rendered in the Ingmar decision is applicable in the case of application of the Rome I regulation as well. Case C-381/98 Ingmar GB Ltd v Eaton Leonard Technologies Inc. [2000] ECR I-9305 para 48.

37 Case C-184/12 United Antwerp Maritime Agencies (Unamar) NV v Navigation Maritime Bulgare [17 October 2013] ECLI:EU:C:2013:663. 
what substantive requirement does a national provision have to meet in order to be classified as overriding mandatory in nature. ${ }^{38}$

As a consequence of the two judgments of the CJEU there is another layer one has to add to the analyses of the overriding mandatory norms. Namely, in cases that are connected exclusively with EU MS, the scope of mandatory rules that are at the same time internationally mandatory i.e. that are overriding mandatory rules, is narrower than in other cases. In this layer of analyses, it has to be shown that the mandatory norm protects the highest public interests and passes the full proportionality test. ${ }^{39}$

The Rome II Regulation on the law applicable to non-contractual obligations ${ }^{40}$ as well as the regulations on matrimonial property regimes ${ }^{41}$ and on the property consequences of registered partnerships ${ }^{42}$ allow the application of the overriding mandatory provisions of the forum.

Article 16 of the Rome II Regulation was interpreted in the da Silva Martins case. ${ }^{43}$ The dispute occurred on the issue as to whether Article 16 of the Rome II Regulation must be interpreted as meaning that a national provision which provides that the limitation period for actions seeking compensation for damage resulting from an accident is three years, may be considered to be an overriding mandatory provision, within the meaning of that article. The Court decided that it cannot be considered to be an overriding mandatory provision, within the meaning of that article, unless the court hearing the case finds, on the basis of a detailed analysis of the wording, general scheme, objectives and the context in which that provision was adopted, that it is of such importance in the national legal order that it justifies a departure from the law applicable. ${ }^{44}$ The Court gave clear instructions to interpret the article 16 of the Rome II Regulation in line with the interpretation of article 7 of the Rome Convention and article 9 of the Rome I Regulation. ${ }^{45}$

\subsection{OVERRIDING MANDATORY NORMS OF THIRD COUNTRIES}

According to article 9 para 3, third countries' overriding mandatory rules apply only if they belong to the law of the state of the place of performance of the contractual obligations, and only where the effect of these rules is to render the performance illegal. This provision is more restrictive than the one provided by the Rome Convention which allowed for the application

38 Giesela Rühl, 'Commercial Agents, Minimum Harmonization and Overriding Mandatory Provisions in the European Union: Unamar' (2016) 53(1) Common Market Law Review 223.

Regulation (EC) No 864/2007 of the European Parliament and of the Council of 11 July 2007 on the law applicable to noncontractual obligations (Rome II) [2007] OJ L199/40 art 16.

Council Regulation (EU) 2016/1103 of 24 June 2016 implementing enhanced cooperation in the area of jurisdiction, applicable law and the recognition and enforcement of decisions in matters of matrimonial property regimes [2016] OJ L183/1 art 30. Ibid.

Case C-149/18 Agostinho da Silva Martins v Dekra Claims Services Portugal SA [31 January 2019] ECLI:EU:C:2019:84.

Ibid para 35.

Ibid para 28. 
of overriding mandatory norms of a third country in case the law of that country was closely connected to the contract.

The application of the overriding mandatory norms of a third country is considered as a quite controversial issue, but it is today accepted in private international law. The most commonly cited reason why is comity. ${ }^{46}$ However, there are many additional reasons which should be added to the argument in favour of the application of third country provision. The most convincing reason is indeed connected with the situation where a particular contracted obligation has subsequently become illegal according to the law of the place of performance - it would not be reasonable to enforce that contract and to force the party to perform an illegal act. ${ }^{47}$ However, other reasons such as reciprocity, reduction of forum shopping, the effect on the recognition and enforcement of a foreign judgment ${ }^{48}$ are equally convincing to argue that all other third countries' overriding mandatory norms should not be disregarded as irrelevant.

Notwithstanding the fact that the Rome I Regulation explicitly allows only for the application of the overriding mandatory rules of a narrowly defined third country, there is no impediment to giving effect of any other third countries' overriding mandatory norms, as long as those are given only an indirect effect, i.e. as long as those rules are treated as facts whose consideration is governed by the law applicable to the contract. ${ }^{49}$ This approach is in the line with the Giuliano Lagarde report in connection to the article 7 of the Rome Convention and with the idea that the third countries' overriding mandatory norms should always be applied when the connection with that country is strong enough and the regulatory interest of the third county is important. ${ }^{50}$

The stance has been confirmed by the CJEU in the Nikiforidis ${ }^{51}$ judgment. Mr. Nikiforidis was employed by the Hellenic Republic at a Greek primary school in Germany. The question raised by the German Federal Labour Court was whether to apply the Greek Saving Laws Nos. $3833 / 2010$ and $3845 / 2010$ as overriding mandatory provisions which would result in the reduction of mr. Nikifordis' salary.

In its decision the CJEU held that Article 9 of the Rome I Regulation must be interpreted 'as precluding the court of the forum from applying, as legal rules, overriding mandatory provisions other than those of the State of the forum or of the State where the obligations arising out of the contract have to be or have been performed. Consequently, since, according to the referring court, Mr. Nikiforidis's employment contract has been performed in Germany, and the referring court is German, the latter cannot in this instance apply, directly or indirectly, the Greek overriding mandatory provisions which it sets out in the request for a preliminary

46 Calliess (n 1) 740; Adeline Chong, 'The Public Policy and Mandatory Rules of Third Countries in International Contracts' (2006) 2(1) Journal of Private International Law 37.

47 Ibid.

48 Ibid 35-40.

49 The availability of two modes of applying a third country's laws is recognised in Germany which has developed the concepts of Schuldstatuttheorie and Sonderanknüpfungstheorie. Ibid 40; For the thorough explanation on the differences between direct and indirect application of overriding mandatory norms please see: Calliess (n 1) 259-60. 
ruling $\cdot{ }^{52}$ However, the Court confirmed that the rules of Rome I Regulation do not preclude the courts to take the overriding mandatory rules of a third country into account as a matter of fact: 'On the other hand, Article 9 of the Rome I Regulation does not preclude overriding mandatory provisions of a State other than the State of the forum or the State where the obligations arising out of the contract have to be or have been performed from being taken into account as a matter of fact, in so far as this is provided for by a substantive rule of the law that is applicable to the contract pursuant to the regulation'. ${ }^{53}$

The Nikiforidis case finally resolved an issue referred to as the 'unfinished part' of European private international law by allowing the court to apply foreign overriding mandatory provisions of all legal systems as facts - i.e. indirectly. ${ }^{54}$ The conclusion that stems is that the scope of article 9(3) of the Rome I Regulation is not at all much narrower than the scope of article 7(1) of the Rome Convention since the application of both could presumably lead to the same outcome. ${ }^{55}$

The Rome II Regulation on the law applicable to non-contractual obligations ${ }^{56}$ as well as the regulations on matrimonial property regimes ${ }^{57}$ and on the property consequences of registered partnerships ${ }^{58}$ allow the application of the overriding mandatory provisions of the forum. Those acts do not, however, explicitly allow the application of overriding mandatory norms of any other country.

However, the same reasoning that allows the indirect application of the overriding mandatory norms of a third country other than the norms that belong to the law of the place of performance can be adopted to defend the position that the mentioned regulations allow the indirect application of an overriding mandatory provision of a third country, if the third country is closely connected to the dispute at hand, i.e. its application as a fact.

\section{OVERRIDING MANDATORY NORMS IN THE CROATIAN PRIVATE INTERNATIONAL LAW SYSTEM}

\subsection{THE OVERRIDING MANDATORY NORMS IN CROATIAN LAW AND PRACTICE BEFORE THE 2017 CROATIAN PIL ACT}

When Croatia, on July $1^{\text {st }}, 2013$, joined the European Union, the definition of the overriding mandatory rules found in article 9 of the Rome I Regulation became a part of the private

\footnotetext{
52 Ibid para 50.

53 Ibid para 52.

54 Kurt Siehr, 'Mandatory Rules of Third States from Ole Lando to Contemporary European Private International' (2020) 28(3) European Review of Private Law 552.

55 Ibid.

56 Regulation (EC) No 864/2007 of the European Parliament and of the Council of 11 July 2007 on the law applicable to noncontractual obligations (Rome II) [2007] OJ L199/40 art 16.

57 Council Regulation (EU) 2016/1103 (n 41) art 30.

58 Ibid.
} 
international law rules on contracts. Definition of the overriding mandatory provisions was a novelty in the Croatian legal system, as the overriding mandatory rules, although applied in Croatia, were not defined in any other legal act.

At that time, the national private international law act in effect in Croatia was the 'Act concerning the resolution of conflicts of laws with the provisions of other countries in certain matters' (Zakon o rješavanju sukoba zakona s propisima drugih zemalja u određenim odnosima). ${ }^{59}$ Private international law has been codified in Croatia since 1982 when the Private International Law Act was originally enacted as a federal statute of the former Socialist Federative Republic of Yugoslavia. ${ }^{60}$ The original text of the law was taken over as the law of Croatia in 1991, when the country declared independence. ${ }^{61}$ The Private International Law Act has not been affected by the major legislative reforms carried out in 1990s, when Croatia underwent a transition from a socialist economy to a market-based economy.

Notwithstanding the lack of a definition under the old private international law act, scholars and practitioners unanimously held that overriding mandatory provisions are a part of the Croatian private international law system. ${ }^{62}$

Before the definition introduced through the European private international law, there were some definitions provided by the scholars. However, most of them relied on the wellknown definitions provided in foreign literature, such as the one by Francescakis according to which overriding mandatory provisions are provisions the respect for which is regarded as crucial by a country for safeguarding its public interests, such as its political, social or economic organisation; ${ }^{63}$ or the one provided by Pierre Mayer according to which overriding mandatory norm is a norm which has to be applied in the state that has rendered it in any case connected to that state. ${ }^{64}$

According to a unanimous interpretation of the application of the overriding mandatory provisions in the Croatian legal literature, the court always applies the overriding mandatory norms of the lex fori. Professor Sikirić, in his paper devoted to the application of the overriding mandatory norms in arbitration wrote that those types of norms are drafted with the intention of their usage in purely domestic situations, i.e. situations without an international element, but notwithstanding their primary aim they cover all types of situations including the ones with an international element and that as a consequence they exclude the application of the foreign law altogether. Thus, overriding mandatory provisions should be applied without going into analyses of which law would be applicable otherwise. ${ }^{65}$ The courts should, in a way, disregard the existence of the international element and directly proceed with the overriding

Zakon o rješavanju sukoba zakona s propisima drugih zemalja u određenim odnosima = Act concerning the resolution of conflicts of laws with the provisions of other countries in certain matters (SL 43/1982, 72/1982, NN 53/1991) (HR).

Official Gazette SFRY (SL 43/1982, 72/1982) (YU)

61 Davor Babić, 'Private International Law' in Tatjana Josipović (ed), Introduction to the Law of Croatia (Wolters Kluwer 2014) 439. The only major change since 1982 was that the rules on recognition and enforcement of arbitral awards were abolished and replaced by the Zakon o arbitraži = Arbitration Act (NN 88/2001) (HR) art 50.

62 Sajko (n 2) 279-82; Tibor Varadi and others, Međunarodno privatno pravo (Pravni fakultet u Beogradu 2016) 173-74.

63 Francescakis (n 4) 13.

64 Pierre Mayer, Le lois de police étrangères (JDI 1981) 287. 
mandatory norm of its own law. The newly introduced definition of overriding mandatory norms of the 2019 PIL Act should be interpreted in the same way. ${ }^{66}$

Both legal literature and practice are unanimous in the conclusion that the overriding mandatory norms of the lex causae should always be applied. ${ }^{67}$ The lex causae overriding mandatory norms are applicable as an integral part of the lex causae. ${ }^{68}$

The old Croatian Private International Law Act ${ }^{69}$ did not provide a definition of the overriding mandatory provisions, however, it did include one substantive law provision that was in essence an overriding mandatory provision. As an interesting peculiarity, ${ }^{70}$ the 1982 Croatian Private International Law Act did incorporate a substantive family law provision that was in essence an overriding mandatory rule. Article 32 of the 1982 PIL Act read:

'The law governing the conditions under which a marriage may be entered into is for each person, the law of the state of which he is national at the date the marriage is entered into.

Even when the requirements to enter into a marriage are fulfilled according to the law of the state, of which the person who wants to enter into a marriage before the competent body of the Republic of Croatia is a national, the marriage shall not be allowed if, with respect to that person, there is, according to the law of the Republic of Croatia, an impediment which relates to the existence of an earlier marriage, kinship or mental incapacity.'

The three impediments to the conclusion of marriage in Croatia - namely, the existence of an earlier marriage, kinship and the mental incapacity - were interpreted to form a part of the public policy in Croatia and, thus, this was an overriding mandatory provision that was included in the PIL Act. ${ }^{71}$ This also shows the unclear delimitation of the public policy exception and the overriding mandatory norms which lead to its overlap in practice.

The new 2019 Private International Law Act does not include a similar provision on the impediments to the conclusion of a marriage in Croatia, however since it does include a specific definition and a provision on the application of the overriding mandatory provisions in general, it can be safely assumed that according to the 2019 PIL Act these particular impediments to marriage can be acknowledged as overriding mandatory provisions as well. ${ }^{72}$

66 Hrvoje Sikirić, 'Zakon o međunarodnom privatnom pravu' (2018) 25 Godišnjak: aktualnosti hrvatskog zakonodavstva i pravne prakse 88 .

67 Sikirić (n 3) 87.

68 Sikirić (n 66) 90. Professor Sikirić further argues that the protection of the domestic legal system in case of the application of the overriding mandatory norms of the lex cause comes in the form of the public policy provision.

69 Zakon o rješavanju sukoba zakona s propisima drugih zemalja u određenim odnosima (n 59).

70 Comparatively, it is very rare to find overriding mandatory provisions among the provisions of the private international law acts. Such example in the EU is found in the Italian private international law system. Article 32 of the Italian Private International Law Act labels impediments for the conclusion of registered partnerships as overriding mandatory norms (norme di applicazione necessaria). Article 33 of the Italian Private International Law Act labels provisions stipulating the uniqueness of the status of the child as overriding mandatory provisions (norme di applicazione necessaria).

71 Mihajlo Dika, Gašo Knežević and Srđan Stojanović, Komentar Zakona o međunarodnom privatnom i procesnom pravu (Nomos 1991) 114; Petar Bosnić, Hrvatsko međunarodno privatno pravo: obrazloženje i komentar Zakona, vol 1 (Pravni fakultet u Splitu 1999) 127; Sajko (n 2) 9. 
In Croatian legal literature there is an opinion that the provision of the Croatian Competition $\mathrm{Act}^{73}$ according to which the Act is applied in all cases in which the Croatian market is affected should be considered to be an overriding mandatory provision. ${ }^{74}$ However, according to dissenting opinion the provision is a unilateral conflict-of-laws rule. ${ }^{75}$

Since the Croatian legislature did not explain what overriding mandatory norms are, nor did it provide guidelines as to who should and in what way determine that a norm is indeed an overriding mandatory one, it does not come as a surprise that there are no published decisions of the Croatian courts that explicitly point out that a certain provision is an overriding mandatory one. In theory, judges should apply standard methods of interpretation to determine whether a norm is an overriding mandatory provision. The decision should be made through a two-step system. The first step in that decision should be whether the rule is mandatory in its nature. The question whether a norm is mandatory or dispositive in its nature should be decided in accordance with the legislators' intent, and in cases where the intent is not obvious it should be interpreted based on the aim of the provision at hand. ${ }^{76}$ The second step is to determine whether the provision aims to protect the highest public interests, i.e. the judge should interpret whether the legislators' intent was to protect a public interest by the respective mandatory norm. ${ }^{77}$

Overriding mandatory provisions are mandatory norms which serve for safeguarding Croatian public interests, such as political, social or economic organisation. Those provisions can be a part of public or private law. ${ }^{78}$ The provisions that are most often mentioned by the scholars include: provisions of criminal law, labour law, tax law, the provisions on confiscation and expropriation of estate, provisions on social security, provisions on the acquisition of real estate, exchange rate legislation, provisions on competition law, provisions on import and export of goods, tariff laws, some commercial law provisions, some financial law provisions etc.

There are some provisions that primarily aim at the protection of a private interest but at the same time their application serves to protect a wider public interest and thus, those types of rules, can also be interpreted as overriding mandatory provisions. An example might be the rules aimed at the protection the bankruptcy debtor's creditors. ${ }^{79}$

However, there are no published decision that confirm or rebut those doctrinal opinions. It seems that the judges are reluctant to decide that a norm indeed should be applied as an overriding mandatory one. On the other hand, there are some cases where the courts have applied the public policy exception and decided to apply the Croatian substantive law where a

\footnotetext{
73 Zakon o zaštiti tržišnog natjecanja = Competition Act (NN 79/09, 80/13) (HR) art 2.

74 Sajko (n 2) 279.

75 Vilim Bouček, 'Hrvatski Zakon o zaštiti tržišnog natjecanja iz 2003. i mjerodavno pravo za izvanugovornu odgovornost za štetu' (2004) 4(10) Hrvatska pravna revija 39-46.

76 Dora Zgrabljić Rotar and Tena Hoško, 'Zaštita cedentovih stečajnih vjerovnika kod cesije s međunarodnim obilježjem' (2019) 69(1) Zbornik Pravnog fakulteta u Zagrebu 108.

77 Ibid.

78 Sikirić (n 3) 86.

79 Zgrabljić Rotar (n 76) 109.
} 
foreign law was applicable according to the private international law rules. Presumably that is a consequence of the existence of a legislative regulation of the ordre public.

According to Article 4 of the 1982 Private International Law Act, 'the law of a foreign state shall not apply if that would be contrary to the basic principles of state organisation laid down by the Constitution of the Republic of Croatia'. In all legal and scholarly texts that analyse the overriding mandatory norms the authors delimit overriding mandatory provisions and the ordre public clause. The courts may refuse to apply foreign law only if the specific result reached by applying that law would violate ordre public. On the other hand, overriding mandatory norms are applicable irrespective of the law applicable according to the conflict of laws rules. However, overriding mandatory norms are often described as a part of the public policy.

Court decisions rarely discuss whether or not applying a particular foreign rule of law would violate Croatian public policy, although the parties often invoke the public policy exception during proceedings. In one, often criticized, decision the High Commercial Court of Croatia held that Czech law, which the parties had chosen as applicable, violates the Croatian public policy. ${ }^{80}$ The court held that the contract at issue created a severe disparity of rights and obligations, in favour of the Czech party. However, the court did not explain which particular principle of Croatian law would have been violated and why that principle should be elevated to the rank of public policy. ${ }^{81}$

This overlap between the application of the ordre public exception and the overriding mandatory norms in practice is not reserved for the Croatian legal system. It is commonly argued that the two concepts have a vague distinction in practice. ${ }^{82}$ National courts are often more willing to rely on the public policy exception.

\subsection{OVERRIDING MANDATORY PROVISIONS AFTER THE 2017 CROATIAN PIL ACT}

With the need for reform of private international law, the bill for a new Private International Law Act was passed by the Croatian Parliament on 4 October 2017 and came into effect on 29 January $2019 .{ }^{83}$

The new Croatian Private International Law Act introduced, for the first time, a comprehensive definition of overriding mandatory provisions in national legislation. The definition of overriding mandatory provisions in article 13 of the Croatian PIL Act reads: 'Notwithstanding other provisions of this Act, the court can apply a provision of Croatian law which is regarded as crucial for safeguarding Croatian public interests, such as political, social or economic organisation, to such an extent that they are applicable to any situation falling within their scope, irrespective of the law otherwise applicable.' The definition provided in the Croatian PIL 2019 is almost a verbatim copy of the definition of the overriding mandatory provisions

80 Court ruling Pž-2008/04-3, High Commercial Court (16 May 2007) (HR).

81 Davor Babić and Dora Zgrabljić Rotar, 'The application of the Rome I and Rome II Regulations in Croatia' in Emmanuel Guinchard (ed), Rome I and Rome II in Practice (Intersentia 2020) 150-51.

82 Chong (n 46) 32.

83 Zakon o međunarodnom privatnom pravu = Private international law act (NN 101/2017) (HR). 
found in article 9 of the Rome I Regulation. This is not surprising since the Croatian PIL Act was drafted a couple of years after Croatia joined the EU - thus, under a significant influence of the European private international law.

According to the wording of the new PIL Act the court can apply a provision of Croatian law which is regarded as an overriding mandatory rule.

Article 13 of the 2019 PIL Act which defines overriding mandatory provisions, and its first paragraph determines the mandatory application of such provisions of lex fori, in paragraph 2 states:

'If the performance of a particular obligation is in its entirety or partially contrary to the provision of the law of the foreign country where the obligation is to be fulfilled, the court may give effect to that provision. In consideration whether to give effect to those provisions, regard shall be had to their nature and purpose and to the consequences of their application of non-application.'

This provision limits the application of overriding mandatory provision of a foreign country to the ones that are dealing with the fulfilment of obligations. The provision is very similar to the one in article 9 paragraph 3 of the Rome I Regulation and thus it is unclear why is it also included in the national PIL Act because one might argue that it is redundant.

Namely, the 2019 PIL Act extends the scope of application of the Rome I Regulation to those contracts that are excluded from the scope of application of the Regulation. ${ }^{84}$

Rome I Regulation applies, in situations involving a conflict of laws, to contractual obligations in civil and commercial matters and does not apply, in particular, to revenue, customs or administrative matters (Article 1). Article 1 further sets forth a list of contractual obligations or other related matters that are explicitly excluded from the scope of application of the Regulation. Nothing in the Regulation, or EU law in general, precludes Member States from creating rules on excluded matters as they see fit, including by an extension of the rules of the Rome I Regulation. ${ }^{85}$

According to Article 25(2) of the 2017 Croatian Private International Law Act, the law applicable to contractual obligations that fall outside of the scope of application of the Rome I Regulation and are not governed by another provision of national or international law in force in Croatia, is determined according to the provisions of the Rome I Regulation applicable to such contractual obligations.

The same extension of the scope of application has been provided in the case of the Rome II Regulation. Namely, according to Article 26(2) of the 2017 Croatian Private International Law Act, the law applicable to non-contractual obligations that fall outside of the scope of application of the Rome II Regulation, and are not governed by another provision of national or international law in force in Croatia, are is determined according to the provisions of the Rome II Regulation applicable to those non-contractual obligations.

\footnotetext{
84 Ibid art 25(2).

85 Calliess (n 1$) 58$.
} 
Thus, it remains unclear whether and when the provision of Article 13 paragraph 3 of the 2019 PIL Act can be applied and what was the intention of the legislator when it included it.

It should also be noted that in the context of the overriding mandatory norms of the lex fori, the PIL Act uses the expression 'the court can apply', while as in the case of application of the overriding mandatory provisions of a third country the term used is 'can give effect to'.

Notwithstanding the ambiguities in the regulation of the application of the third countries' overriding mandatory norms, the fact that the Croatian legislator introduced the possibility of the application of the third country overriding mandatory norms points to the conclusion that it would be, in the least, acceptable to give the overriding mandatory provisions of a third country an indirect effect. That would, also be consistent with the European private international law and the recent practice of the CJEU in its decision Nikiforidis.

\section{CONCLUSION ON THE APPLICATION OF THE OVERRIDING MANDATORY NORMS BY CROATIAN COURTS AND PRACTITIONERS}

When faced with a situation with an international element, the first step for every practitioner is to determine which conflict-of-laws rules are applicable in that particular situation. This first step can sometimes present as a challenge. However, it is crucial for the proper application of the applicable law.

In case of the application of overriding mandatory provisions, Croatian practitioners have a slightly less complicated task since the Croatian legislator has relied on the definition and interpretation of the overriding mandatory norms as provided in the European private international law. This means that notwithstanding whether a court is applying the 2017 Croatian Private International Law Act or a European regulation, it can rely on the same definition of the overriding mandatory norms and it can apply very similar tools to interpret a provision to determine whether it is an overriding mandatory one.

The first step is to determine that the provision in question is a mandatory norm. It will be a mandatory norm if it protects the internal public policy of a country. The second step is to decide that it protects the highest public interests of a country and should that be considered mandatory in situations with an international element.

The main question, thus, is - which provisions protect the highest public interests of a country? There is no simple answer nor a formula, however there are some safe guidelines that can be applied. Firstly, the provision can be a private law provision or a public law provision. It can be a provision that protects private interests as long as it serves a broader public interest, as decided by the CJEU in the Ingmar and Unamar cases.

If the court has to apply a regulatory norm, it is safe to assume that such a norm can be applied as an overriding mandatory provision, however it has to be certain that it protects the highest interests of a country. 
If the court is deciding on the application of an overriding mandatory norm of the lex fori it will have an easier task than deciding whether a norm protects the highest public interests in a foreign legal system. The court can apply an overriding mandatory norm of a third country if it renders the performance of the obligation unlawful. The court can in any other case take into account and apply indirectly (as a fact) any other overriding mandatory norm of a third country, as decided by the CJEU in the Nikiforidis case.

Finally, the applications of mandatory provisions in situations with an international element should not be confused with the application of the ordre public exception. In the case of the application of the public policy exception the court has to decided that the effects of the application of the foreign law are contrary to the public policy of the lex fori, while as when apply the overriding mandatory norms the court has to make sure that those provision aim at the protection of the highest public interests of the country.

\section{BIBLIOGRAPHY}

1. Babić D, 'Private International Law' in Tatjana Josipović (ed), Introduction to the Law of Croatia (Wolters Kluwer 2014) 439-54

2. Babić D and Zgrabljić Rotar D, 'The application of the Rome I and Rome II Regulations in Croatia' in Emmanuel Guinchard (ed), Rome I and Rome II in Practice (Intersentia 2020)

3. Bosnić P, Hrvatsko međunarodno privatno parvo: obrazloženje i komentar Zakona, vol 1 (Pravni fakultet u Splitu 1999)

4. Bouček V, 'Hrvatski Zakon o zaštiti tržišnog natjecanja iz 2003. i mjerodavno pravo za izvanugovornu odgovornost za štetu' (2004) 4(10) Hrvatska pravna revija 39

5. Calliess GP, Rome Regulations - Commentary (2nd edn, Wolters Kluwer 2015)

6. Chong A, 'The Public Policy and Mandatory Rules of Third Countries in International Contracts' (2006) 2(1) Journal of Private International Law 27

7. Cordero-Moss G, 'EU Overriding Mandatory Provisions and the Law Applicable to the Merits' in F Ferrari (ed), The Impact of EU Law on Commercial Arbitration (Juris 2017) 317-49

8. Dickinson A, "Third-Country Mandatory Rules in the Law Applicable to Contractual Obligations: So Long, Farewell, Auf Wiedersehen, Adieu?' (2007) 3(1) Journal of Private International Law 53-88

9. Dika M, Knežević $\mathrm{G}$ and Stojanović S, Komentar Zakona o međunarodnom privatnom i procesnom pravu (Nomos 1991)

10. Francescakis $P$, 'Quelques précisions sur les "lois d'application immediate” et leurs rapports avec les règles sur les conflits de lois' [1966] 55 RCDIP 1

11. Hellner M, 'Third Country Overriding Mandatory Rules in the Rome I Regulation: Old Wine Bottles?' (2009) 5(3) Journal of Private International Law 449

12. Hesselink MW, 'Non-Mandatory Rules in European Contract Law' (2005) 1(1) European Review of Contract Law 44

13. Kunda I, 'Defining Intenationally Mandatory Rules in European Private International Law of Contracts' (2007) 4(5) Zeitschrift für Gemeinschaftsprivatrecht 210

14. Kunda I, 'Međunarodno prisilni propisi prema Europskom sudu pravde: C-381/98 Ingmar GB Ltd protiv Eaton Leonard Technologies Inc.' (2004) 6(1-2) Revija za evropsko pravo 55 
15. Lehmann $M$, 'Regulation, global governance and private international law: squaring the triangle' (2020) 16(1) Journal of Private International Law 1

16. Magnus U and Mankowski P, European Commentaries on Private International Law: Rome I Regulation (Sellier 2017)

17. Martiny D, 'Rom I-VO Art. 14 Rom I-VO Übertragung der Forderung' in Franz Jürgen Säcker and others (eds), Münchener Kommentar zum Bürgerlichen Gesetzbuch: BGB (CH Beck 2018)

18. Mayer P, Le lois de police étrangères (JDI 1981) 277-345

19. Nygh P, Autonomy in International Contracts (Clarendon Press 1999)

20. Rühl G, 'Commercial Agents, Minimum Harmonization and Overriding Mandatory Provisions in the European Union: Unamar' (2016) 53(1) Common Market Law Review 209

21. Sajko K, Međunarodno privatno pravo (Narodne novine 2009)

22. Siehr K, 'Mandatory Rules of Third States From Ole Lando to Contemporary European Private International' (2020) 28(3) European Review of Private Law 509

23. Sikirić H, 'Prisilna pravila, pravila neposredne primjene i mjerodavno materijalno pravo u međunarodnoj arbitraži' (1999) 38(1) Pravo u gospodarstvu 83

24. Sikirić H, 'Zakon o međunarodnom privatnom pravu' (2018) 25 Godišnjak: aktualnosti hrvatskog zakonodavstva i pravne prakse 61

25. Varadi T and others, Međunarodno privatno pravo (Pravni fakultet u Beogradu 2016)

26. Zgrabljić Rotar D and Hoško T, 'Zaštita cedentovih stečajnih vjerovnika kod cesije s međunarodnim obilježjem' (2019) 69(1) Zbornik Pravnog fakulteta u Zagrebu 89

\section{REGULATIONS AND DOCUMENTS}

1. Convention on the law applicable to contractual obligations opened for signature in Rome on 19 June 1980 [1980] OJ L 266/1

2. Council Regulation (EU) 2016/1103 of 24 June 2016 implementing enhanced cooperation in the area of jurisdiction, applicable law and the recognition and enforcement of decisions in matters of matrimonial property regimes [2016] OJ L183/1

3. Council Regulation (EU) 2016/1104 of 24 June 2016 implementing enhanced cooperation in the area of jurisdiction, applicable law and the recognition and enforcement of decisions in matters of the property consequences of registered partnerships [2016] OJ L183/30

4. Regulation (EC) No 593/2008 of the European Parliament and of the Council of 17 June 2008 on the law applicable to contractual obligations (Rome I) [2008] OJ L177/6

5. Regulation (EC) No 864/2007 of the European Parliament and of the Council of 11 July 2007 on the law applicable to non-contractual obligations (Rome II) [2007] OJ L199/40

6. Report on the Convention on the law applicable to contractual obligations by Mario Giuliano, Professor, University of Milan, and Paul Lagarde, Professor, University of Paris I [1980] OJ C282/1

7. Zakon o arbitraži = Arbitration Act (NN 88/2001) (HR)

8. Zakon o međunarodnom privatnom pravu = Private international law act (NN 101/2017) (HR)

9. Zakon o rješavanju sukoba zakona s propisima drugih zemalja u određenim odnosima = Act concerning the resolution of conflicts of laws with the provisions of other countries in certain matters (SL 43/1982, 72/1982, NN 53/1991) (HR)

10. Zakon o zaštiti tržišnog natjecanja = Competition Act (NN 79/09, 80/13) (HR) 


\section{JUDGMENTS AND OTHER DECISIONS}

1. Case C-135/15 Republik Griechenland v Grigorios Nikiforidis [18 October 2016] ECLI:EU:C:2016:774

2. Case C-149/18 Agostinho da Silva Martins v Dekra Claims Services Portugal SA [31 January 2019] ECLI:EU:C:2019:84

3. Case C-184/12 United Antwerp Maritime Agencies (Unamar) NV v Navigation Maritime Bulgare [17 October 2013] ECLI:EU:C:2013:663

4. Case C-381/98 Ingmar GB Ltd v Eaton Leonard Technologies Inc. [2000] ECR I-9305

5. Conclusion ECLI:NL:PHR:1967:AC1306, Public prosecutor's office at the Supreme Court [NJ 1967, no 3 Alnaty] (10 March 1967) (NL)

6. Court ruling Pž-2008/04-3, High Commercial Court (16 May 2007) (HR)

7. Court ruling Rev-x 876/13-3, Supreme Court of the Republic of Croatia (30 September 2014) (HR)

8. Joined Cases C-369/96 and C-376/96 Criminal proceedings against Jean-Claude Arblade and Arblade \& Fils SARL and Bernard Leloup, Serge Leloup and Sofrage SARL [1999] ECR I-8453 


\section{PRAVILA NEPOSREDNE PRIMJENE U HRVATSKOM MEĐUNARODNOM PRIVATNOM PRAVU}

\section{Sažetak}

Pravila neposredne primjene prisilni su propisi koji se primjenjuju i u pravnim odnosima s međunarodnim obilježjem. Autorica analizira uređenje pravila neposredne primjene prema europskom međunarodnom privatnom pravu i prema hrvatskom nacionalnom međunarodnom privatnom pravu. Definicija pravila neposredne primjene uvedena Zakonom o međunarodnom privatnom pravu iz 2017. godine gotovo je identična kao i definicija koju je u sustav europskog međunarodnog privatnog prava uvela odredba članka 9. Uredbe Rim o pravu mjerodavnom za ugovorne obveze. Zakon o rješavanju sukoba zakona s propisima drugih zemalja u određenim odnosima iz 1982. godine nije spominjao pravila neposredne primjene, ali je njihova primjena bila prihvaćena brojnim tumačenjima. Štoviše, u ZRS uvršten je bio jedan prisilni propis obiteljskog materijalnog prava koji se smatra pravilom neposredne primjene. Ipak, osim navedenog izričitog pravila iz područja obiteljskog prava, sudovi u Hrvatskoj nisu spremno primjenjivali prisilne propise i u situacijama s međunarodnim obilježjem. Razloge možemo tražiti u nedostatku zakonske regulacije takvih pravila, kao i u činjenici da je ZRS izričito uređivao institut javnog poretka čija se primjena u praksi često teško razgraničava od primjene pravila neposredne primjene te, ne manje važno, nužnosti sudske interpretacije prisilnog propisa kao pravila neposredne primjene. Utvrditi da je neko materijalno pravilo prisilni propis koji se primjenjuje i u situaciji s međunarodnim obilježjem složen je zadatak. Autorica u ovom radu nastoji pružiti neke smjernice za pomoć pri ispunjavanju tog zadatka.

Ključne riječi: $\quad$ pravila neposredne primjene, prisilni propisi, Uredba Rim I, Zakon o međunarodnom privatnom pravu iz 2017. godine

\section{(c) (1) (8)}

This work is licensed under a Creative Commons

Attribution-NonCommercial 4.0 International License.

Dr. sc. Dora Zgrabljić Rotar, docentica Pravnog fakulteta Sveučilišta u Zagrebu, Trg Republike Hrvatske 14, 10000 Zagreb. E-adresa: dora.zgrabljic.rotar@pravo.hr. ORCID: https://orcid.org/0000-0002-6558-4532. 